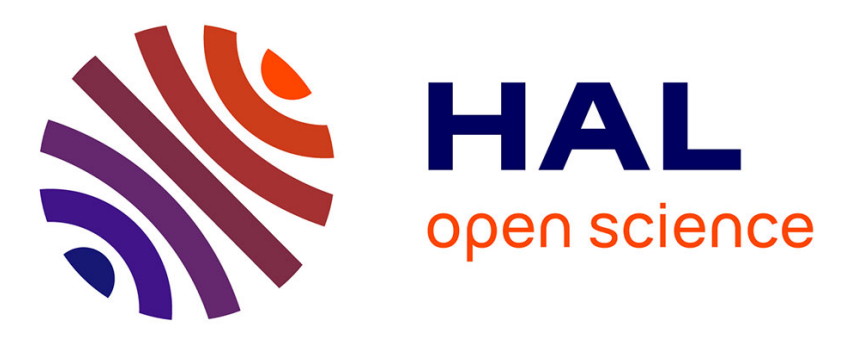

\title{
Rutin inhibits proliferation, attenuates superoxide production and decreases adhesion and migration of human cancerous cells
}

\author{
Mohamed Ben Sghaier, Alessandra Pagano, Mohamed Mousslim, Youssef \\ Ammari, Hervé Kovacic, José Luis
}

\section{To cite this version:}

Mohamed Ben Sghaier, Alessandra Pagano, Mohamed Mousslim, Youssef Ammari, Hervé Kovacic, et al.. Rutin inhibits proliferation, attenuates superoxide production and decreases adhesion and migration of human cancerous cells. Biomedicine and Pharmacotherapy, 2016, 84, pp.1972-1978. 10.1016/j.biopha.2016.11.001 . hal-01474951

\section{HAL Id: hal-01474951 \\ https://hal-amu.archives-ouvertes.fr/hal-01474951}

Submitted on 2 Mar 2017

HAL is a multi-disciplinary open access archive for the deposit and dissemination of scientific research documents, whether they are published or not. The documents may come from teaching and research institutions in France or abroad, or from public or private research centers.
L'archive ouverte pluridisciplinaire HAL, est destinée au dépôt et à la diffusion de documents scientifiques de niveau recherche, publiés ou non, émanant des établissements d'enseignement et de recherche français ou étrangers, des laboratoires publics ou privés. 


\title{
Rutin inhibits proliferation, attenuates superoxide production and decreases adhesion and migration of human cancerous cells
}

\author{
Mohamed ben Sghaier, ${ }^{\mathrm{a}, *}$, Alessandra Pagano ${ }^{\mathrm{b}, \mathrm{c}}$, Mohamed Mousslim ${ }^{\mathrm{b}, \mathrm{c}}$, \\ Youssef Ammari ${ }^{\mathrm{a}}$, Hervé Kovacic ${ }^{\mathrm{b}, \mathrm{c}}$, José Luis ${ }^{\mathrm{b}, \mathrm{c}}$ \\ ${ }^{a}$ Laboratory for Forest Ecology, National Institute for Research in Rural Engineering, Water and Forests, University of carthage, BP 10, 2080 Ariana, Tunisia \\ ${ }^{\mathrm{b}}$ Centre de Recherche en Oncologie Biologique et Oncopharmacologie (CRO2), INSERM UMR 911, Faculté de Pharmacie, Marseille, France \\ c Aix-Marseille Université, France
}

\section{A R T I C L E I N F O}

\section{Article history:}

Received 4 July 2016

Received in revised form 1 November 2016

Accepted 1 November 2016

\section{Keywords:}

Lung cancer

Colorectal cancer

Rutin

Superoxide production

Adhesion

Migration

\section{A B S T R A C T}

Lung and colorectal cancer are the principal causes of death in the world. Rutin, an active flavonoid compound, is known for possessing a wide range of biological activities.

In this study, we examined the effect of rutin on the viability, superoxide anion production, adhesion and migration of human lung (A549) and colon (HT29 and Caco-2) cancer cell lines. In order to control the harmlessness of the tested concentrations of rutin, the viability of cancer cell lines was assessed using a 3-(4,5-dimethylthiazol- 2-yl)-2,5-diphenyl-tetrazolium bromide (MTT) assay. ROS generation was measured by lucigenin chemiluminescence detecting superoxide ions. To investigate the effect of rutin on the behavior of human lung and colon cancer cell lines, we performed adhesion assays, using various purified extracellular matrix (ECM) proteins. Finally, in vitro cell migration assays were explored using modified Boyden chambers. The viability of cancerous cells was inhibited by rutin. It also significantly attenuated the superoxide production in HT29 cells. In addition, rutin affected adhesion and migration of A549 and HT29 cell.

These findings indicate that rutin, a natural molecule, might have potential as anticancer agent against lung and colorectal carcinogenesis.

(c) 2016 Elsevier Masson SAS. All rights reserved.

\section{Introduction}

Lung cancer is one of the principal causes of death in the world, and non-small cell lung carcinoma accounts for approximately $75 \%-85 \%$ of all lung cancers [1]. Furthermore, colorectal cancer (CRC) is the second most common cancer diagnosed in women [2] and the third in men [3], with an overall survival rate of only 5 years due to resistance to cytostatic drugs [4]. Consequently, novel therapeutic agents are needed to deal with the increasing incidence of human lung and colorectal cancer. Several reports including animal studies have shown that increased consumption of plant-based diet can reduce the risk of cancer such as lung and colon cancer [5,6].

The production of reactive oxygen species (ROS) by eukaryotic cells is believed to be related to the formation of ROS as toxic byproducts of various cellular metabolic processes. Recently, the importance of controlled ROS production by nonphagocytic cells, including lung epithelial cells, in the regulation of physiological

\footnotetext{
* Corresponding author.

E-mail address: medbensghaier@gmail.com (M. ben Sghaier).
}

functions has been suggested in many studies [7]. However, the bioactive cancer preventives remain to be identified. Herbal-based dietary supplements contain a large array of phytochemicals including the flavonoids which might mediate physiological functions related to cancer suppression.

Cancer preventive properties of natural compounds have been studied extensively; however, very little in relation to lung carcinogen [8]. In this context, there is no preceding work dealing with the action of rutin on lung cancer cells. Nevertheless, it was previously described the dietary intervention of polyphenols in cancer prevention, including the chemopreventive ability of dietary flavonoids, act against lung carcinogens. In vitro studies were performed over a wide range of polyphenols which showed significant effect in lung Cancer, such as epigallocatechin-3-gallate (EGCG), suppresses in a dose dependent manner, the hexavalent chromium ( $\mathrm{Cr}(\mathrm{VI})$ )-induced apoptosis, reduces activation of caspase-3 and nuclear poly (ADP-ribose) polymerase (PARP), and intracellular ROS [9]. It has also been demonstrated, that Caffeic acid can scavenge intracellular ROS and hence prevent lipid peroxidation in WI-38 cells [10]. Lim et al. [11] revealed that Catechol, a naturallyoccurring compound found in fruits and vegetables such as onions, 
apples and olive oil, suppressed anchorage-independent growth of murine KP2 and human H460 lung cancer cell lines in a dosedependent manner and inhibited ERK2 kinase activity. In Vivo polyphenols studies of lung cancer prevention were also conducted in experimental mice models [12-17].

Rutin is found in many typical plants such as buckwheat, apples, black tea, and vegetables. It also exists in many traditional chinese medicines [18]. Many beneficial effects of rutin have been identified, including inhibition of platelet aggregation, being anti-inflammatory, antioxidant, and reducing blood fat and cholesterol $[19,20]$. Furthermore, it was previously described that rutin induced in vitro cytotoxic effects on cancer cell lines [21,22] including human colon cancer cells $[23,24]$. Rutin and their analogues, such as EGCG and quercetin, act as efficient radical inhibitors and have been shown to have chemopreventive activity in both a variety of colonic cancer cell lines and in murine models [25-27]. Moreover, rutin has shown antitumor effects in some in vivo models such as NK/Ly ascites and B16F10 cells [21,22,28]. Therefore, it was also illustrated that rutin exerted significant beneficial effects on decreasing the amount of precancerous lesions and inducing apoptosis in the large intestine cancer and human neuroblastoma LAN-5 cells $[29,30]$.

Despite the evidence for its several biological activities, the anticancer effects of rutin on human colon cancer cells remain to be explored. We also examined, for the first time, the effect of rutin on lung cancer cells adhesion and migration using several purified extracellular matrix (ECM) proteins. In addition, we investigated the potential antiproliferative and antioxidant activities of rutin in human lung (A549) and colon (HT29 and Caco-2) cancer cell lines.

\section{Materials and methods}

\subsection{Chemicals and reagents}

Rutin was purchased from Extrasynthèse (Genay,France) and it was of the highest available purity.

Dulbecco's modified Eagle's medium (DMEM) and RPMI 1640 medium were purchased from Lonza (Levallois-Perret, France). Penicillin, streptomycin, fetal bovine serum (FBS), trypsin-EDTA, Lglutamine, and sodium pyruvate were purchased from GIBCO (Cergy-Pontoise, France). Methylthiazolyldiphenyl-tetrazolium bromide (MTT), lucigenin, poly-L-lysine, human fibrinogen and mouse laminin-1 was from Sigma (St Quentin Fallavier, France). Rat type I collagen was from Upstate (Lake Placid, NY, USA) and human fibronectin from Millipore (St Quentin en Yvelines, France).

\subsection{Tumors cell lines and culture conditions}

Human lung (A549) cells were cultured in RPMI 1640 medium, Colon (HT29 and Caco-2) cells were maintained in Dulbecco's modified Eagle's medium (DMEM), all the mediums were supplemented with $10 \%$ foetal bovine serum (FBS), supplemented with $2 \mathrm{mM} \mathrm{L-glutamine}$ and $1 \%$ sodium pyruvate and were maintained at $37^{\circ} \mathrm{C}$ in a humidified atmosphere with $5 \% \mathrm{CO} 2$.

\subsection{Cell viability assay}

Cell viability was assessed by MTT assay after $24 \mathrm{~h}$ incubation. For each cell line, $70 \%$ confluent cell culture flask was trypsinized and the cells were seeded in 96 well plates at a density of 5000 cells by well in the appropriate complete media; $24 \mathrm{~h}$ after seeding, the cells were treated with increasing concentrations of rutin or control vehicle solution (DMSO $0.1 \%$ in phosphate saline buffer); $72 \mathrm{~h}$ after treatment, the cells were exposed to $0.5 \mathrm{mg} / \mathrm{ml}$ of MTT for $3 \mathrm{~h}$ at $37^{\circ} \mathrm{C}$ in the appropriate complete medium. Medium and MTT were removed and after solubilization in dimethylsulfoxide (DMSO), the amount of insoluble formazan crystals was evaluated by measuring the optical density at $550 \mathrm{~nm}$. Each condition was performed in triplicate.

\subsection{Measurement of ROS}

ROS generation was measured by lucigenin chemiluminescence detecting superoxide ions [31]. After incubation of the cells for the desired time with drugs in 96 -well plates $\left(50 \times 10^{3}\right.$ cells/well), luminescence was detected by a Fluoroscan Ascent FL fluorimeter (Labsystems, France). The detected signal was assessed at each minute over the course of $45 \mathrm{~min}$. The results represent the integration of the signal for $45 \mathrm{~min}$ which is associated with the inter-mediate time of measurement. All measurements were performed at $37^{\circ} \mathrm{C}$ and the results were expressed as total reactive oxygen species measurements which represent the difference of reactive oxygen species production measured in untreated control.

\subsection{Cell adhesion assay}

Adhesion assays were performed as previously described [32]. Briefly, flat bottom 96-well microtiter plates were coated with one of the following purified extracellular matrix (ECM) proteins: fibronectin $(10 \mu \mathrm{g} / \mathrm{ml})$, vitronectin $(10 \mu \mathrm{g} / \mathrm{ml})$, laminin $1(10 \mu \mathrm{g} /$ $\mathrm{ml})$, fibrinogen $(50 \mu \mathrm{g} / \mathrm{ml})$, collagen type I and IV $(10 \mu \mathrm{g} / \mathrm{ml})$, polyL-lysine (10 and $50 \mu \mathrm{g} / \mathrm{ml}$ ) and were blocked with BSA. The cells were harvested in single cell suspension and resuspended in DMEM and RPMI containing 0.2\% BSA (adhesion buffer) in the presence or absence of rutin. After incubation for $30 \mathrm{~min}$ at room temperature, the cells were added to coated wells in a volume of $50 \mu \mathrm{l}\left(10^{6}\right.$ cells $\left./ \mathrm{ml}\right)$ and allowed to adhere to the substrate for $1 \mathrm{~h}$ (A549 cells) and $2 \mathrm{~h}$ (HT29 cells) at $37^{\circ} \mathrm{C}$. Unattached cells were removed by gently washing three times with adhesion buffer. Residual attached cells were fixed by $1 \%$ glutaraldehyde, stained by $0.1 \%$ crystal violet and lysed with $1 \%$ SDS. Absorbance was then measured at $600 \mathrm{~nm}$ by a microplate reader.

\subsection{Cell migration assays using modified Boyden chambers}

In vitro cell migration assays were performed using modified Boyden chambers (NeuroProbe Inc, Bethesda, MD, USA) as previously described [33]. Briefly, membranes were coated with fibronectin or collagen type IV $(10 \mu \mathrm{g} / \mathrm{ml})$ for $2 \mathrm{~h}$ at $37^{\circ} \mathrm{C}$ and blocked with a solution of $0.1 \%$ BSA/PBS. The cells harvested as a single cell suspension were added to precoated membranes and allowed to migrate for $5 \mathrm{~h}$ at $37^{\circ} \mathrm{C}$. Migrated cells were stained by $0.1 \%$ crystal violet, lysed with $1 \%$ SDS and cell migration was then quantified by measurement of the absorbance at $600 \mathrm{~nm}$.

\subsection{Wound healing assay}

A549 and HT29 cells migration was assayed by wound/healing assay as described previously [34]. Confluent cells in 35-mmdiameter dishes were damaged by scraping with a sterile pipette tip $(500 \mu \mathrm{m}$ in diameter). The cultures were washed twice with phosphate-buffered saline to remove cellular debris. Vehicle control and various concentrations of rutin were added to the respective wells for the indicated times. After $18 \mathrm{~h}$, the cells that had migrated into the denuded area were photographed using an Olympus inverted microscope. Migration was quantified by measuring covered surface.

\subsection{Statistical analysis}

The results were expressed as means \pm S.D. from at least three independent experiments. Statistical analysis was performed using 
unpaired Student's test. The value of $P<0.05$ was considered statistically significant.

\section{Results}

\subsection{Cell viability in tumors cell lines}

We first evaluated the cytotoxicity of rutin $(31.25-1000 \mathrm{mM})$ after $24 \mathrm{~h}$ of incubation on the different cancer cell lines (A549, HT29 and Caco-2) using MTT assay. As illustrated in Fig. 1, rutin was able to inhibit the viability of A549, HT29 and Caco-2 cells in a dose-dependent manner. A significant difference in growthinhibitory effects of this compound on A549, HT29 and Caco-2 cells was revealed. Rutin was most efficient in HT29 cell with an estimated $\mathrm{IC}_{50}$ value of $388.33 \pm 4 \mu \mathrm{M}$ after $72 \mathrm{~h}$. However, A549 and Caco- 2 cells seemed to be more resistant to flavonoid treatment with $\mathrm{IC}_{50}$ values of $559.83 \pm 3.5 \mu \mathrm{M}$ and $710.59 \pm 3.5$ respectively.

\subsection{ROS scavenger activity of rutin}

As high level of ROS production exists in tumor cells, ROS production has been linked either to the cell proliferation or cell death. We investigated the effect of rutin on superoxide anion production in the different cell lines. The superoxide reducing ability of rutin is shown in Fig. 2. It appears that the superoxide anion reducing effect was dose dependent in the presence of rutin. Therefore, the maximum reducing effect of rutin was observed at a concentration of $100 \mu \mathrm{M}$ against HT29 cells with a reduction percentage of $64.41 \pm 2 \%$. However, at this concentration, rutin was able to reduce superoxide anion production with a reduction percentage of $56.65 \pm 3$ and $31.12 \pm 1.5 \%$ against A549 and Caco- 2 cells respectively. This result indicates that rutin is more effective in HT29 cells.

\subsection{Rutin affects adhesion of tumour cells}

It has long been known that most cell types require attachment to grow. As rutin inhibits tumor cell proliferation, we investigated whether it can act through the blocking of cell attachment. In order to investigate the rutin effects on the behaviour of human nonsmall cell lung cancer A549 and HT29 colonic adenocarcinoma cells, we first performed cell adhesion assays using a large array of purified ECM proteins.

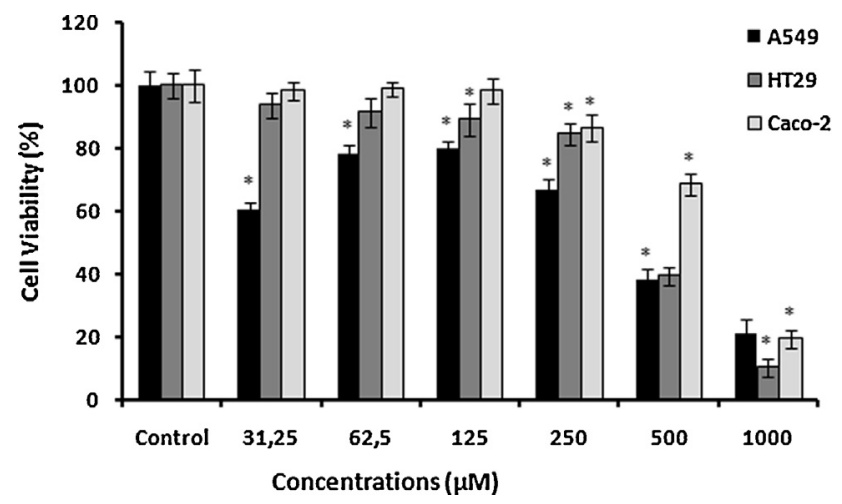

Fig. 1. The Inhibitory effect of rutin on the proliferation of Human lung (A549) and colon (HT29 and Caco-2) cancer cell lines. Cells were plated at $5 \times 10^{3}$ cells per dish in the absence and the presence of rutin $(31.25-1000 \mu \mathrm{M})$. Time-dependent decrease in the number of Human lung (A549) and colon (HT29 and Caco-2) cancer cell at the indicated concentrations. As control, the cells were treated without or with $0.1 \%$ DMSO (vehicle). Data are means \pm S.D., $n=3$ per group.

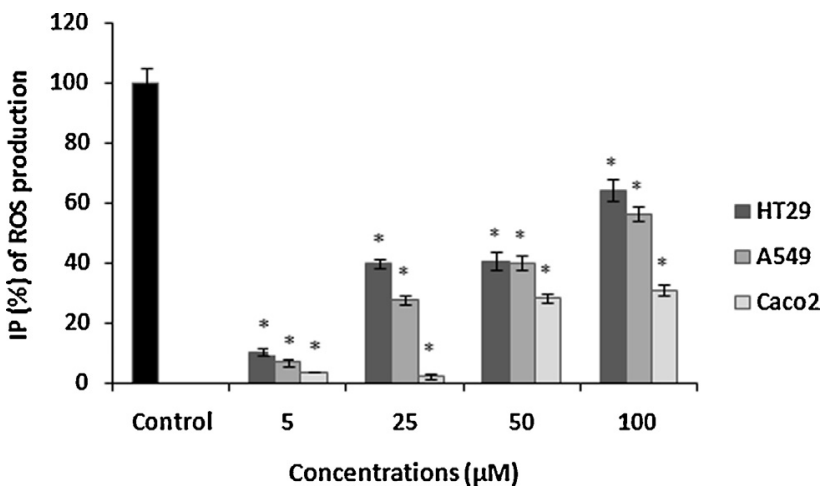

Fig. 2. Production of $\mathrm{O}_{2}{ }^{-}$in Human lung (A549) and colon (HT29 and Caco-2) cancer cell lines exposed to rutin $(5-100 \mu \mathrm{M})$. Production of $\mathrm{O}_{2}{ }^{-}$was determined by lucigenin luminescence. The cells were plated at $50 \times 10^{3}$ cell/well. Data from at least three independent experiments have been pooled. Rutin significantly decreased $\mathrm{O}_{2}^{-}$production in the A549 cell compared with untreated cells $\left({ }^{*} \mathrm{P}<0.05\right)$. Data are means \pm S.D., $\mathrm{n}=3$ per group.

As illustrated in Fig. 3, rutin impaired attachment in a dosedependent manner of both A549 and HT29 cells to fibronectin (inhibition of cell adhesion by $47 \pm 2.5 \%$ for A549 cells and $38 \pm 1.9 \%$ for HT29 cells in presence of rutin $200 \mu \mathrm{M})$. An
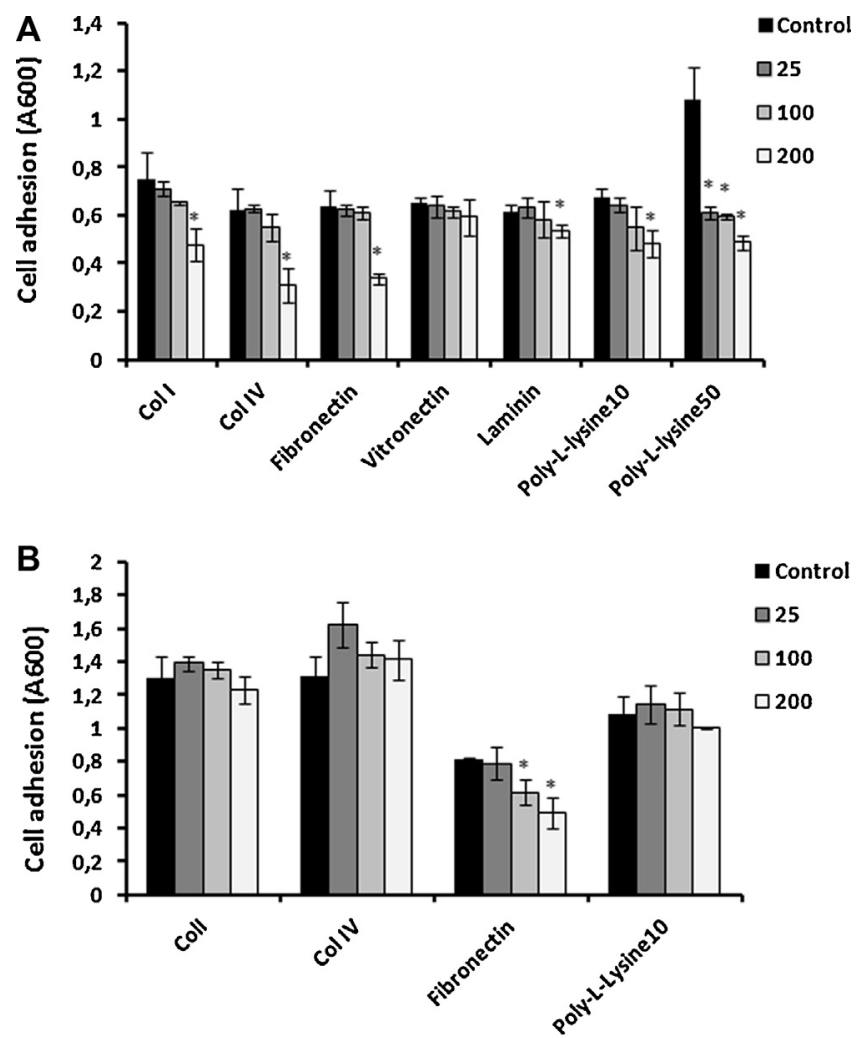

Fig. 3. Ruitn inhibits cell adhesion. (A) A549 cells were seeded at $10^{6}$ cells $/ \mathrm{ml}$ and were preincubated with various concentrations of rutin $(25,100$ and $200 \mu \mathrm{M})$ for $30 \mathrm{~min}$ at room temperature. The cells were then added to 96 -well microtiter plates coated with fibronectin $(10 \mu \mathrm{g} / \mathrm{ml})$, vitronectin $(10 \mu \mathrm{g} / \mathrm{ml})$, laminin $1(10 \mu \mathrm{g} / \mathrm{ml})$, fibrinogen $(50 \mu \mathrm{g} / \mathrm{ml})$, collagen type I and IV $(10 \mu \mathrm{g} / \mathrm{ml})$, poly-L-lysine (10 and $50 \mu \mathrm{g} / \mathrm{ml}$ ) and allowed to adhere for $1 \mathrm{~h}$ at $37^{\circ} \mathrm{C}$. (B) HT29 cells were seeded at $10^{6}$ cells $/ \mathrm{ml}$ and were preincubated with various concentrations of rutin $(25,100$ and $200 \mu \mathrm{M}$ ) for $30 \mathrm{~min}$ at room temperature. The cells were then added to 96 -well microtiter plates coated with fibronectin $(10 \mu \mathrm{g} / \mathrm{ml})$, collagen type I and IV $(10 \mu \mathrm{g}$ $\mathrm{ml}$ ) and poly-L-lysine $(10 \mu \mathrm{g} / \mathrm{ml})$ and allowed to adhere for $2 \mathrm{~h}$ at $37^{\circ} \mathrm{C}$. After washing, adherent cells were stained with crystal violet, solubilized by SDS and absorbance was measured at $600 \mathrm{~nm}$. Data are means ( \pm S.D) of at least three independent experiments and expressed as a percentage of adhesion. * indicates statistically significant results compared to control $(\mathrm{p}<0.05)$. 
impairment of attachment to collagen type I and IV was observed in A549 (inhibition of cell adhesion by $36.6 \pm 2$ and $50.2 \pm 3 \%$ respectively). In contrast, no effect of rutin in attachment of HT29 cells to collagen type I and IV was observed (Fig. 3).

\subsection{Rutin inhibits tumor cell migration}

Cell migration can be considered as a finely regulated process including successive steps of cell adhesion and de-adhesion. Because rutin inhibits A549 and HT29 cell adhesion, we also examined its effect on cell migration using a haptotaxis assay in modified Boyden chambers. As shown in Fig. 4, rutin at 100 and $200 \mu \mathrm{M}$ blocked A549 and HT29 cell migration. This inhibition was dose-dependent with migration percentage of $47.9 \pm 1.5$ and $38.61 \pm 1 \%$ in the presence of type IV collagen and $52.75 \pm 1$ and $9.48 \pm 0.5 \%$ in the presence of fibronectin towards A549 cells with rutin at 100 and $200 \mu \mathrm{M}$, respectively. For HT29 cells, the migration percentage values were $55.19 \pm 2.5$ and $37.63 \pm 1.5 \%$ towards type IV collagen and $54.49 \pm 3$ and $37.82 \pm 2 \%$ towards fibronectin with rutin at 100 and $200 \mu \mathrm{M}$, respectively. The effect of rutin was also confirmed by using wound/healing assay. Scrape damaged A549 and HT29 monolayers were incubated in the presence of rutin $(25-200 \mu \mathrm{M})$ for $18 \mathrm{~h}$. Control cells completely covered the wounded area after $18 \mathrm{~h}$ of incubation at $37^{\circ} \mathrm{C}$. In contrary, treatment with rutin strongly reduced wound repair and significantly inhibited the migration of both A549 (Fig. 5A and B) and HT29 (Fig. 5C and D) cells in a concentration-dependent manner.

A
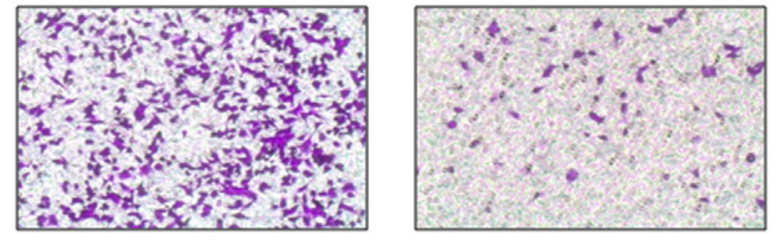

Control (Col IV)

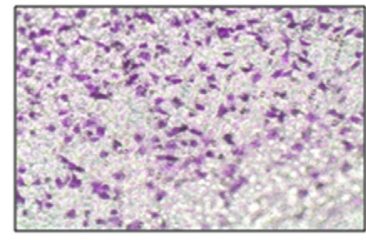

Control (Fn)

B

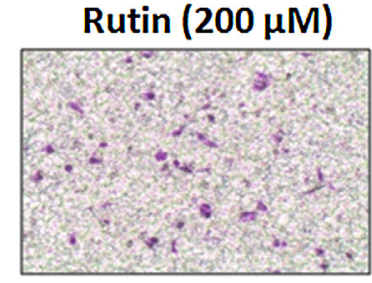

Rutin $(200 \mu \mathrm{M})$

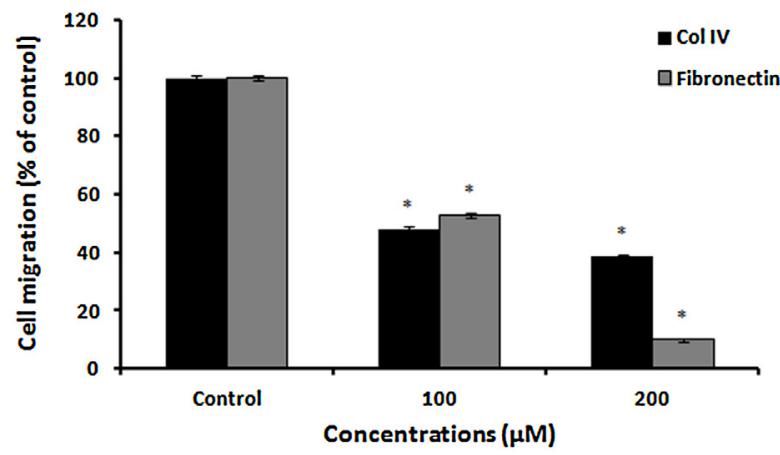

\section{Discussion}

Natural plant extracts and their flavonoids have been shown to display anti-cancer properties both in vitro and in vivo. The discovery of bioactive compounds as well as the clarification of their mechanism in the anticancer activity is crucial. Rutin, one of the major representatives of flavonoids, is present in many natural plants [35]. It has been used in a wide range of pharmacological applications. However, current research has shown its multispectral pharmacological benefits for the treatment of various chronic diseases such as cancer, diabetes, hypertension, and hypercholesterolemia [24,36-38]. In this study, we investigated the antitumour potential of rutin in terms of inhibition of cell viability, superoxide production, adhesion and migration of human cancerous cells.

The effect of rutin on the proliferation of human lung (A549) and colon (HT29 and Caco-2) cancer cell lines was studied for $72 \mathrm{~h}$ period. The proliferation of the various tested cell lines was significantly inhibited by rutin over a concentration range of 31.25$1000 \mu \mathrm{M}$ in a dose-dependent manner. Rutin has shown cytotoxic effects on several human cancer cells $[21,22,39]$ including human colorectal cancer cells $[23,24]$. Our results corroborate the cytotoxic effects of rutin previously reported. Araujo et al. [40] showed that rutin is able to inhibit cancer cell growth by cell cycle arrest and/or apoptosis, along with inhibition of proliferation, angiogenesis, and/or metastasis in colorectal cell lines. Moreover, other studies demonstrated the same effect of rutin on human U138MG and GL-15 glioma cell lines and murine leukemia WEHI-3

C

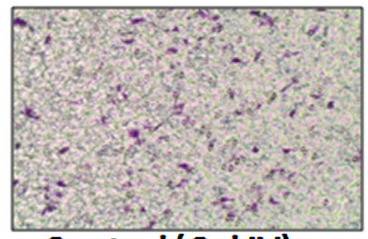
Control (Col IV)

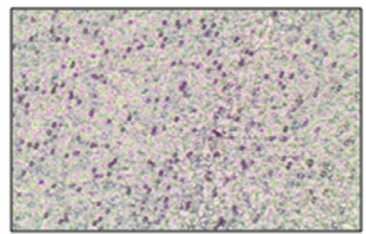

Control (Fn)

D

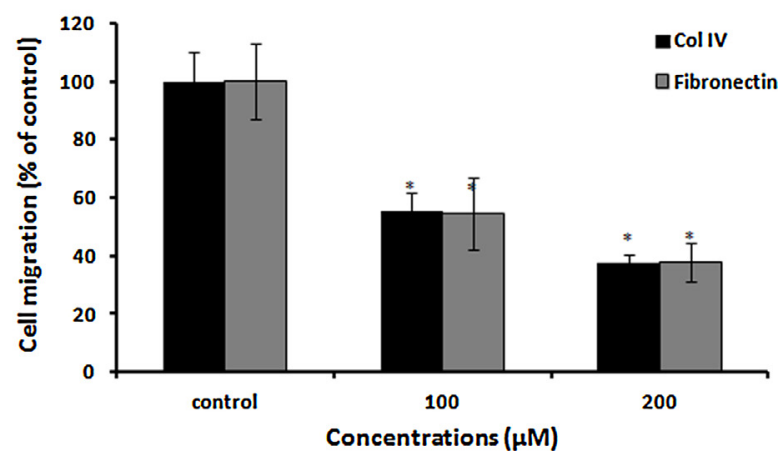

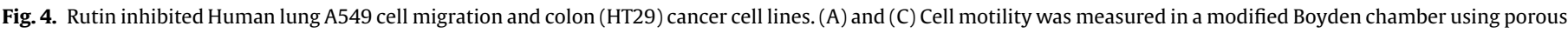

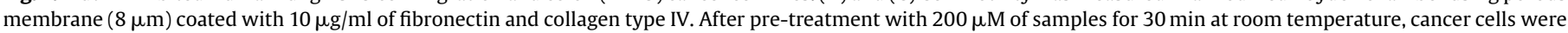

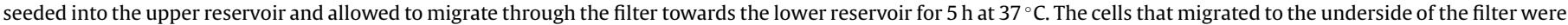

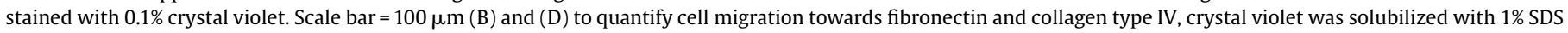
and absorbance was measured at $600 \mathrm{~nm}$. Data are means $\pm S . D ; n=3$ per group. ${ }^{*}$ indicates statistically significant results compared to control ( $\mathrm{p}<0.05$ ). 
A

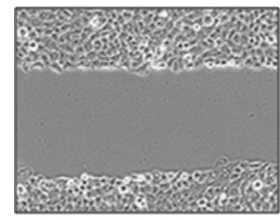

Control

$t(0)$

B

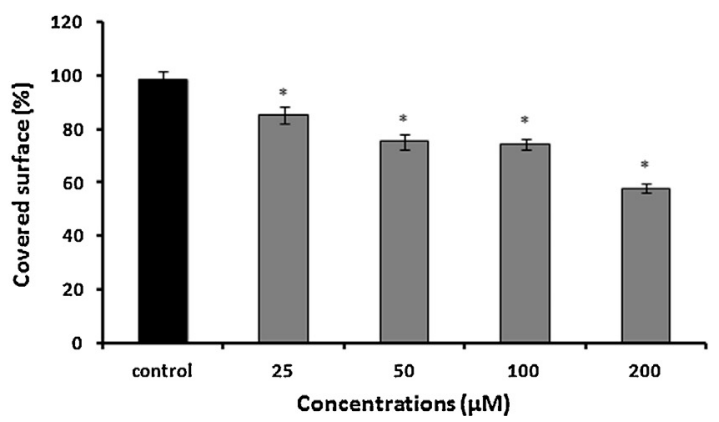

C
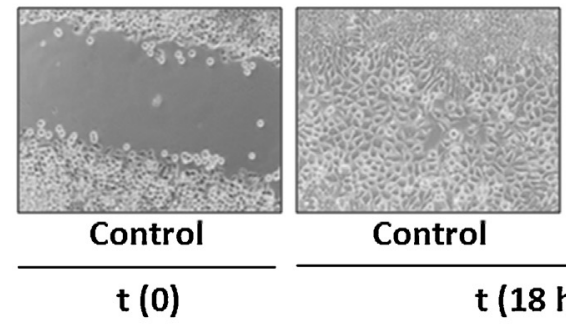

Control

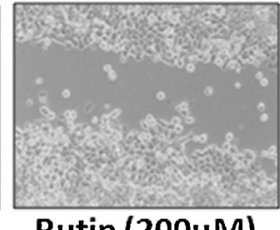

Rutin $(200 \mu \mathrm{M})$

$t(18 \mathrm{~h})$

D

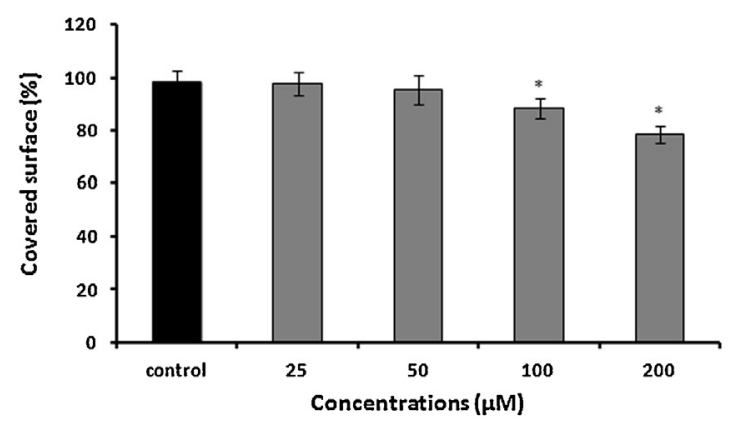

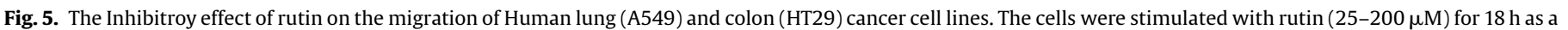

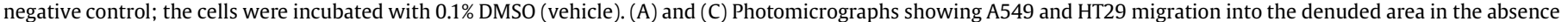

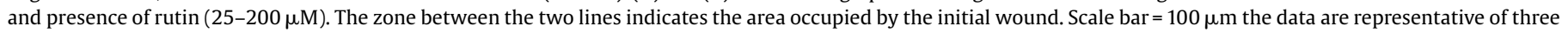

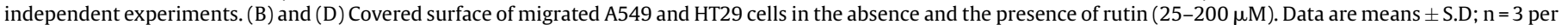
group. * indicates statistically significant results compared to control $(\mathrm{p}<0.05)$.

cells [41]. Compared to quercetin, rutin demonstrated a range of different effects, either inhibiting [42-45] or not altering colorectal cancer cell proliferation [46]. Furthermore, rutin showed a less antiproliferative potential against HT-29, HCT 116, MCF-7, HepG2, and A549 cells, but the transformation of rutin to quercetin-3- $\beta-D-$ glucoside showed the most potent growth inhibition [47].

ROS are highly reactive molecules that can impair cell structures such as carbohydrates, nucleic acids, lipids and proteins and alter their function [48]. The oxidative stress is considered a fundamental factor in increasing persistent degenerative disorders, such as coronary heart diseases, cancer and aging [49,50].

Previous studies have suggested that the anticancer effect of many antioxidants may be due to their capability to scavenge free radicals [51,52]. Some tumor cells, such as human colon adenocarcinoma HT29 and melanoma HCT15 cells can produce high levels of ROS [53]. In the present study, we confirmed that the ROS level decreased in all the tested tumor cell lines after rutin treatment particularly in HT29 cells.

Rutin, is also known as Vitamin P and has antiplatelet, antiviral, and antihypertensive properties, as well as strength in the capillaries, which are the result of its high radical scavenging activity and antioxidant capacity [54]. Gong et al. [55] found that rutin protected human vein endothelium cells (HUVEC) against $\mathrm{H}_{2} \mathrm{O}_{2}$-induced apoptotic cell death. It that study, the protective effects of rutin was attributed to regulation of glutathione reactive oxygen species.

Rutin analog quercetin (quercetin rutinoside) has been reported to reduce both the risk and progression of cancer through their decrease in ROS production [56,57]. It protects cells from oxidative stress, inflammation, and DNA damage due to its antioxidant properties and modulates growth of many cancer cell lines by blocking cell cycle progression in the G0/G1 phase, the G2/Mphase, and the S-phase, reducing tumor cell proliferation, inducing apoptosis and caspase- 3 activity and inhibition of VEGF production [58-63].
Furthermore, quercetin also known to enhance the GSH/GSSG ratio and the catalase activity in melanoma cells. In the study of Kim [64], it was described that quercetin decrease and modulate the ROS production induced melanogenesis not only by reducing the total level of all reactive species but also by developing the antioxidative $\mathrm{ONOO}^{-}$scavenging performance, the GSH/GSSG ratio and catalase activity in melanoma cells.

A relevant interest is present on the mechanisms of action of chemopreventers, especially concerning the identification of molecular and cellular targets of natural compounds, and the molecular basis of their cancer-preventive action. Indeed, the possible role in cancer chemoprevention of flavonoids can be attributed to their capacity of quenching ROS, reactive nitrogen species (RNS) and other radicals [65]. Additionally, flavonoids exert their potential antioxidant effect not only by quenching ROS, but also by modulating the activity of several detoxifying enzymes, including lipoxygenase, cycloxygenase, inducible nitric oxide synthase, monoxygenase, xanthine oxidase and NADH oxidase [66-68]. Among enzymes that are inhibited by flavonoids, thioredoxin reductases have to be quoted, as they are involved in cellular redox control, and are overexpressed in different aggressive tumors [69]. Moreover, Flavonoids induce apoptosis or caspase activity, inhibit cell proliferation and/or cyclin-dependent kinases cancer (CDK) activities and also block different cell cycles from cell lines [50].

Considering the presence of polyphenols in vegetables and other foods [70], they can therefore be used in the remedy or as complementary agents in the treatment of cancer [50,71]. Currently, the development of herbal medicines for the inhibition of angiogenesis, in combination with conventional anticancer therapies, is amongst the most intensively studied approaches for cancer prevention [72,73].

Cell adhesion is a critical process in many biological phenomena such as development, tissue structure maintenance, angiogenesis, and tumour metastasis. In the absence of appropriate ECM contacts, mainly mediated by integrins, the cells undergo 
programmed cell death $[74,75]$. Therefore, the characterization of new anti-integrin agents is of considerable utility for the development of therapies [76].

In the present study, we demonstrated that rutin affected adhesion of A549 mainly on all the tested matrix and HT29 cells, particularly on fibronectin. This effect could lead to the suppression of the constitutive integrin activation, disrupt cell-ECM interactions and block the tumor adhesion process via influencing the CAMs expressions. In relation study, Nasr Bouzaiene et al. [77] demonstrated that the phenolic acids affect adhesion of A549 and HT29-D4 cells.

Cancer cell metastasis involves multistep cellular processes, commencing with cell migration and invasion. Cell migration is tightly regulated by coordinated remodeling of membrane and actin cytoskeleton. Although the detailed mechanisms are not yet understood, it is clear that dynamic and reciprocal interactions between cell adhesion molecules, ECM and soluble factors are essential.

The inhibitory effect of rutin on cell migration is likely due to the reduced attachment to ECM proteins observed in the presence of this flavonoid. The same effect was observed with others flavonoids against lung cancer A549 cells and human colorectal adenocarcinoma DLD1 and SW480 cells $[78,79]$.

\section{Conclusion}

In summary, the findings of the current study show, for the first time, that rutin was used as a multifunctional agent to decrease cell adhesion and migration of human lung and colon cancer cells, to inhibit proliferation and to reduce the production of ROS. All these results showed that rutin can be one of the major effective ingredients in the therapeutic effect of cancer diseases. Further studies are necessary to improve our understanding of thetherapeutic effects of rutin.

\section{Conflict of interest}

The authors declare that they have no conflict of interest.

\section{Acknowledgments}

This work was supported by AVERROES program. The authors acknowledge Pr. Boukataya Samir (English teacher at the Faculty of Dental Medicine, Tunisia) for English editing.

\section{References}

[1] H. Al Husaini, P. Wheatley-Price, M. Clemons, F.A. Shepherd, Prevention and management of bone metastases in lung cancer: a review, J. Thorac. Oncol. 4 (2009) 251-259.

[2] M.M. Center, A. Jemal, R.A. Smith, E. Ward, World wide variations in colorectal cancer, CA Cancer J. Clin. 59 (6) (2009) 366-378.

[3] L.A. Torre, F. Bray, R.L. Siegel, J. Ferlay, J. Lortet-Tieulent, A. Jemal, Global cancer statistics 2012, CA Cancer J. Clin. 65 (2015) 87-108.

[4] L. Dahan, A. Sadok, J.L. Formento, J.F. Seitz, H. Kovacic, Modulation of cellular redox state underlies antagonism between oxaliplatin and cetuximab in human colorectal cancer cell lines, Br. J. Pharmacol. 158 (2) (2009) 610-620.

[5] M. Mutoh, M. Takahashi, K. Fukuda, H. Komatsu, T. Enva, Y. Matsushima-Hibiya, H. Mutoh, T. Sugimura, K. Wakabayashi, Suppression by flavonoids of cyclooxygenase-2 promoter-dependent transcriptional activity in colon cancer cells: structure-activity relationship, Jpn. J. Cancer Res. 91 (2000) 686691.

[6] D. Feskanich, R.G. Ziegler, D.S. Michaud, E.L. Giovannucci, F.E. Speizer, W.C. Willett, G. Colditz, Prospective study of fruit and vegetable consumption and risk of lung cancer among men and women, J. Natl. Cancer Inst. 92 (2000) $1812-1823$.

[7] A. Van der Vliet, NADPH oxidases in lung biology and pathology: host defense enzymes, and more, Free Radic. Biol. Med. 44 (2008) 938-955.

[8] M. Amararathna, M.R. Johnston, H.P. Vasantha Rupasinghe, Plant polyphenols as chemopreventive agents for lung cancer, Int. J. Mol. Sci. 17 (8) (2016) 13521365.
[9] F. Wu, H. Sun, T. Kluz, H.A. Clancy, K. Kiok, M. Costa, Epigallocatechin-3-gallate (EGCG) protects against chromate-induced toxicity in vitro, Toxicol. Appl. Pharmacol. 258 (2012) 166-175.

[10] K.A. Kang, K.H. Lee, R. Zhang, M.J. Piao, S. Chae, K.N. Kim, Y.J. Jeon, D.B. Park, H.J You, J.S. Kim, J.W. Hyun, Caffeic acid protects hydrogen peroxide induced cell damage in WI-38 human lung fibroblast cells, Biol. Pharm. Bull. 29 (2006) 1820-1824.

[11] D.Y. Lim, S.H. Shin, M.H. Lee, M. Malakhova, I. Kurinov, Q. Wu, J. Xu, Y. Jiang, Z Dong, K. Liu, K.Y. Lee, K.B. Bae, B.Y. Choi, Y. Deng, A. Bode, Z. Dong, A natural small molecule, catechol, induces c-Myc degradation by directly targeting ERK2 in lung cancer, Oncotarget 7 (23) (2016) 35001-35014.

[12] S.T. Chan, C.H. Chuang, C.L. Yeh, J.W. Liao, K.L. Liu, M.J. Tseng, S.L. Yeh, Quercetin supplementation suppresses the secretion of pro-inflammatory cytokines in the lungs of Mongolian gerbils and in A549 cells exposed to benzo[a]pyrene alone or in combination with $\beta$-carotene: in vivo and ex vivo studies, J. Nutr. Biochem. 23 (2012) 179-185.

[13] M.J. Bao, J. Shen, Y.L. Jia, F.F. Li, W.J. Ma, H.J. Shen, L.L. Shen, X.X. Lin, L.H. Zhang, X.W. Dong, Y.C. Xie, Y.O. Zhao, O.M. Xie, Apple polyphenol protects against cigarette smoke-induced acute lung injury, Nutrition 29 (2013) 235-243.

[14] C. Naveenkumar, S. Raghunandakumar, S. Asokkumar, J. Binuclara, B. Rajan, T. Premkumar, T. Devaki, Mitigating role of baicalein on lysosomal enzymes and xenobiotic metabolizing enzyme status during lung carcinogenesis of Swiss albino mice induced by benzo(a)pyrene, Fundam. Clin. Pharmacol. 28 (2014) 310-322.

[15] H. Jin, J.X. Chen, H. Wang, G. Lu, A. Liu, G. Li, S. Tu, Y. Lin, C.S. Yang, NNK-induced DNA methyltransferase 1 in lung tumorigenesis in $\mathrm{A} / \mathrm{J}$ mice and inhibitory effects of (-)-epigallocatechin-3-gallate, Nutr. Cancer 67 (2015) 167-176.

[16] A.E. El-Kenawy, S.S. Elshama, H.H. Osman, Effects of Physalis peruviana L. on toxicity and lung cancer induction by nicotine derived nitrosamine ketone in rats, Asian Pac. J. Cancer Prev. 16 (2015) 5863-5868.

[17] L.N. Bodduluru, E.R. Kasala, R.M. Madhana, C.C. Barua, M.I. Hussain, P. Haloi, P. Borah, Naringenin ameliorates inflammation and cell proliferation in benzo(a) pyrene induced pulmonary carcinogenesis by modulating CYP1A1, NF_B and PCNA expression, Int. Immunopharmacol. 30 (2016) 102-110.

[18] C.H. Wu, M.C. Lin, H.C. Wang, M.Y. Yang, M.J. Jou, C.J. Wang, Rutin inhibits oleic acid induced lipid accumulation via reducing lipogenesis and oxidative stress in hepatocarcinoma cells, J. Food Sci. 76 (2011) T65-72.

[19] H.J. Chan, Y.L. Ji, H.C. Chul, J.K. Chang, Anti-asthmatic action of quercetin and rutin in conscious guinea-pigs challenged with aerosolized ovalbumin, Arch. Pharm. Res. 30 (12) (2007) 1599-1607.

[20] S. Chen, J. Gong, F. Liu, U. Mohammed, Naturally occurring polyphenolic antioxidants modulate IgE-mediated mast cell activation, Immunology 100 (2000) 471-480.

[21] J. Molnar, I. Beladi, K. Domonkos, S. Földeák, K. Boda, A. Veckenstedt, Antitumor activity of flavonoids on NK/Ly ascites tumor cells, Neoplasma 28 (1981) 11-18.

[22] L.G. Menon, R. Kuttan, G. Kuttan, Inhibition of lung metastasis in mice induced by B16F10 melanoma cells by polyphenolic compounds, Cancer Lett. 95 (1995) 221-225.

[23] S. Kuntz, U. Wenzel, H. Daniel, Comparative analysis of the effects of flavonoids on proliferation, cytotoxicity, and apoptosis in human colon cancer cell lines, Eur. J. Nutr. 38 (1999) 133-142.

[24] T.E. Guon, H.A. Sook Chung, Hyperoside and rutin of Nelumbo nucifera induce mitochondrial apoptosis through a caspase-dependent mechanism in HT-29 human colon cancer cells, Oncol. Lett. 11 (2016) 2463-2470.

[25] F. Pu, K. Mishima, K. Irie, K. Motohashi, Y. Tanaka, K. Orito, T. Egawa, Y. Kitamura, N. Egashira, K. Iwasaki, M. Fujiwara, Neuroprotective effects of quercetin and rutin on spatial memory impairment in an 8-arm radial maze task and neuronal death induced by repeated cerebral ischemia in rats, J. Pharmacol. Sci. 104 (2007) 329-334.

[26] E.E. Deschner, J.F. Ruperto, G.Y. Wong, H.L. Newmark, The effect of dietary quercetin and rutin on AOM-induced acute colonic epithelial abnormalities in mice fed a high-fat diet, Nutr. Cancer 20 (1993) 199-204.

[27] N.N. Mahmoud, A.M. Carothers, D. Grunberger, R.T. Bilinski, M.R. Churchill, C. Martucci, H.L. Newmark, M.M. Bertagnolli, Plant phenolics decrease intestinal tumors in an animal model of familial adenomatous polyposis, Carcinogenesis 21 (2000) 921-927.

[28] C. Martínez Conesa, V. Vicente Ortega, M.J. Yáñez Gascón, M. Alcaraz Baños, M. Canteras Jordana, O. Benavente-García, J. Castillo, Treatment of metastatic melanoma B16F10 by the flavonoids tangeretin, rutin, and diosmin, J. Agric. Food Chem. 53 (2005) 6791-6797.

[29] S.R. Volate, D.M. Davenport, S.J. Muga, M.J. Wargovich, Modulation of aberrant crypt foci and apoptosis by dietary herbal supplements (quercetin, curcumin, silymarin, ginseng and rutin), Carcinogenesis 26 (8) (2005) 1450-1456.

[30] H. Chen, Q. Miao, M. Geng, J. Liu, Y. Hu, L. Tian, J. Pan, Y. Yang, Anti-tumor effect of rutin on human neuroblastoma cell lines through inducing G2/M cell cycle arrest andpromoting apoptosis, Sci. World J. (2013) 269165.

[31] K. Irani, Y. Xia, J.L. Zweier, S.J. Sollott, C.J. Der, E.R. Fearon, M. Sundaresan, T. Finkel, P.J. Goldschmidt-Clermont, Mitogenic signaling mediated by oxidants in Ras transformed fibroblasts, Science 275 (1997) 1649-1652.

[32] A. Bazaa, J. Luis, N. Srairi-Abid, O. Kallech-Ziri, R. Kessentini-Zouari, C. Defilles, J.C. Lissitzky, M. El Ayeb, N. Marrakchi, MVL-PLA2 a phospholipase A2 from Macrovipera lebetina transmediterranea venom, inhibits tumor cells adhesion and migration, Matrix Biol. 28 (2009) 188-193. 
[33] E. Delamarre, S. Taboubi, S. Mathieu, C. Berenguer, V. Rigot, J.C. Lissitzky, D. Figarella-Branger, L. Ouafik, J. Luis, Expression of integrin alpha6beta1 enhances tumorigenesis in glioma cells, Am. J. Pathol. 175 (2009) 844-855.

[34] H. Tsuneki, E.L. Ma, S. Kobayashi, N. Sekizaki, K. Maekawa, T. Sasaoka, M.W. Wang, I. Kimura, Antiangiogenic activity of $\beta$-eudesmol in vitro and in vivo, Eur. J. Pharmacol. 512 (2005) 105-115.

[35] G. Gong, Y. Qin, W. Huang, S. Zhou, X. Yang, D. Li, Rutin inhibits hydrogen peroxide-induced apoptosis through regulating reactive oxygen species mediated mitochondrial dysfunction pathway in human umbilical vein endothelial cells, Eur. J. Pharmacol. 628 (1-3) (2010) 27-35.

[36] J.P. Lin, J.S. Yang, J.J. Lin, K.C. Lai, H.F. Lu, C.Y. Ma, R. SaiChuen Wu, K.C. Wu, F.S. Chueh, W. Gibson Wood, J.G. Chung, Rutin inhibits human leukemia tumor growth in a murine xenograft model in vivo, Environ. Toxicol. 27 (8) (2012) 480-484.

[37] T. Koda, Y. Kuroda, H. Imai, Protective effect of rutin against spatial memory impairment induced by trimethyltin in rats, Nutr. Res. 28 (2008) 629-634.

[38] A. Hunyadi, A. Martins, T.J. Hsieh, A. Seres, I. Zupk'o, Chlorogenic acid and rutin play amajor role in the in vivo antidiabetic activity of Morus alba leaf extract on type II diabetic rats, PLoS One 7 (11) (2012) e50619.

[39] A.C. Angel Josabad, D. Fabiola, G.C. Alejandro, Rutin exerts antitumor effects on nude mice bearing SW480 tumor, Arch. Pharm. Res. 44 (2013) 346-351.

[40] J.R. Araujo, P. Gonçalves, F. Martel, Chemopreventive effect of dietary polyphenols in colorectal cancer cell lines, Nutr. Res. 31 (2) (2011) 77-87.

[41] B.L. Santos, A.R. Silva, B.P.S. Pitanga, C.S. Sousa, M.S. Grangeiro, B.O. Fragomeni, P.L.C. Coelho, M.N. Oliveira, N.J. Menezes-Filho, M.F.D. Costa, R.S. El-Bachá, E.S. Velozo, G.P. Sampaio, S.M. Freire, M. Tardy, S.L. Costa, Antiproliferative, proapoptotic and morphogenic effects of the flavonoid rutin on human glioblastoma cells, Food Chem. 127 (2011) 404-411.

[42] S. Kuntz, U. Wenzel, H. Daniel, Comparative analysis of the effects of flavonoids on proliferation, cytotoxicity, and apoptosis in human colon cancer cell lines, Eur. J. Nutr. 38 (1999) 133-142.

[43] W.K. Kim, M.H. Bang, E.S. Kim, N.E. Kang, K.C. Jung, H.J. Cho, J.H. Park, Quercetin decreases the expression of ErbB2 and ErbB3 proteins in HT-29 human colon cancer cells, J. Nutr. Biochem. 16 (2005) 155-162.

[44] J.M. Gee, H. Hara, I.T. Johnson, Suppression of intestinal crypt cell proliferation and aberrant crypt foci by dietary quercetin in rats, Nutr. Cancer 43 (2002) $193-201$.

[45] I.T. Johnson, Anticarcinogenic effects of diet-related apoptosis in the colorectal mucosa, Food Chem. Toxicol. 40 (2002) 1171-1178.

[46] K. Yang, S.A. Lamprecht, Y. Liu, H. Shinozaki, K. Fan, D. Leung, H. Newmark, V.E. Steele, G.J. Kelloff, M. Lipkin, Chemoprevention studies of the flavonoids quercetin and rutin in normal and azoxymethane-treated mouse colon, Carcinogenesis 21 (9) (2000) 1655-1660.

[47] H.J. You, H.J. Ahn, G.E. Ji, Transformation of rutin to antiproliferative quercetin3-glucoside by Aspergillus niger, J. Agric. Food Chem. 58 (20) (2010) $10886-$ 10892.

[48] I.M. Møller, P.E. Jensen, A. Hansson, Oxidative modifications to cellular components in plants, Annu. Rev. Plant Biol. 58 (2007) 459-481.

[49] A. Umeno, H. Masanori, K. Murotomi, Y. Nakajima, Y. Yoshida, Antioxidative and antidiabetic effects of natural polyphenols and isoflavones, Molecules 21 (6) (2016) 708-722.

[50] W.J.K. Wahle, D. Rotondo, I. Brown, D.S. Heys, Plant phenolics in the prevention and treatment of cancer, Bio-Farms for Nutraceuticals, Springer, US: New York, NY, USA, 2010, pp. 36-51.

[51] C. Ding, X. Fan, G. Wu, Peroxiredoxin 1 - an antioxidant enzyme in cancer, J. Cell. Mol. Med. (2016) 1-10, doi:http://dx.doi.org/10.1111/jcmm.12955.

[52] B.W. Lin, C.C. Gong, H.F. Song, Y.Y. Cui, Effects of anthocyanins on the prevention and treatment of cancer, Br. J. Pharmacol. (2016), doi:http://dx.doi. org/10.1111/bph.13627.

[53] A. Gupta, S.F. Rosenberger, G.T. Bowden, Increase ROS levels contribute to elevated transcription factor and MAP kinase activities in malignantly progressed mouse keratinocyte cell lines, Carcinogenesis 20 (1999) 20632073.

[54] A. Korkmaz, D. Kolankaya, Protective effect of rutin on the ischemia/ reperfusion induced damage in rat kidney, J. Surg. Res. 164 (2010) 309-315.

[55] G. Gong, Y. Qin, W. Huang, S. Zhou, X. Yang, D. Li, Rutin inhibits hydrogen peroxide-induced apoptosis through regulating reactive oxygen species mediated mitochondrial dysfunction pathway in human umbilical vein endothelial cells, Eur. J. Pharmacol. 628 (1-3) (2010) 27-35.

[56] A.M. Ekstrom, M. Serafini, O. Nyren, A. Wolk, C. Bosetti, R. Bellocco, Dietary quercetin intake and risk of gastric cancer: results from a population-based study in Sweden, Ann. Oncol. 22 (2011) 438-443.

[57] T.K. Lam, M. Rotunno, J.H. Lubin, S. Wacholder, D. Consonni, A.C. Pesatori, P.A. Bertazzi, S.J. Chanock, L. Burdette, A.M. Goldstein, A.M. Tucker, N.E. Caporaso,
A.F. Subar, M.T. Landi, Dietary quercetin quercetin-gene interaction, metabolic gene expression in lung tissue and lung cancer risk, Carcinogenesis 31 (2010) 634-642.

[58] H.K. Nair, K.V.K. Rao, R. Aalinkeel, S. Mahajan, R. Chawda, S.A. Schwartz Inhibition of prostate cancer cell colony formation by the flavonoid quercetin correlates with modulation of specific regulatory genes, Clin. Diagn. Lab. Immunol. 11 (2004) 63-69.

[59] S.U. Mertens-Talcott, S.S. Percival, Ellagic acid and quercetin interact synergistically with resveratrol in the induction of apoptosis and cause transient cell cycle arrest in human leukemia cells, Cancer Lett. 218 (2005) $141-151$.

[60] J.H. Yang, T.C. Hsia, H.M. Kuo, P.D. Chou, C.C. Chou, Y.H. Wei, J.G. Chung, Inhibition of lung cancer cell growth by quercetin glucuronides via G 2/M arrest and induction of apoptosis, Drug Metab. Dispos. 34 (2006) 296-304.

[61] C. Mu, P. Jia, Z. Yan, X. Liu, X. Li, H. Liu, Quercetin induces cell cycle G1 arrest through elevating Cdk inhibitors p21 and p27 in human hepatoma cell line (HepG2), Methods Find. Exp. Clin. Pharmacol. 29 (2007) 179-183.

[62] J.H. Jeong, J.Y. An, Y.T. Kwon, J.G. Rhee, Y.G. Lee, Effects of low dose quercetin: cancer cell-specific inhibition of cell cycle progression, J. Cell. Biochem. 106 (2009) 73-82.

[63] C.A. Camargo, M.E.F. da Silva, R.A. da Silva, G.Z. Justo, M.C.C. GomesMarcondes, H. Aoyama, Inhibition of tumor growth by quercetin with increase of survival and prevention of cachexia in Walker 256 tumor-bearing rats, Biochem. Biophys. Res. Commun. 406 (4) (2011) 638-642.

[64] Y.J. Kim, Hyperin and quercetin modulate oxidative stress-induced melanogenesis, Biol. Pharm. Bull. 35 (2012) 2023-2027.

[65] L. Gibellini, M. Pinti, M. Nasi, J.P. Montagna, S. De Biasi, E. Roat, L. Bertoncelli, E. L. Cooper, A. Cossarizza, Quercetin and cancer chemoprevention, Evid. Based Complement. Altern. Med. 2011 (2011) 15, doi:http://dx.doi.org/10.1093/ ecam/neq053 ID 591356.

[66] S.Y. Sheu, C.H. Lai, H.C. Chiang, Inhibition of xanthine oxidase by purpurogallin and silymarin group, Anticancer Res. 18 (1) (1998) 263-267.

[67] G.M. Raso, R. Meli, G. Di Carlo, M. Pacilio, R. Di Carlo, Inhibition of inducible nitric oxide synthase and cyclooxygenase-2 expression by flavonoids in macrophage J774A.1, Life Sci. 8 (8) (2001) 921-931.

[68] T. Schewe, H. Kuhn, H. Sies, Flavonoids of cocoa inhibit' recombinant human 5lipoxygenase, J. Nutr. 132 (7) (2002) 1825-1829.

[69] J. Lu, L.V. Papp, J. Fang, S. Rodriguez-Nieto, B. Zhivotovsky, A. Holmgren, Inhibition of mammalian thioredoxin reductase by some flavonoids: implications for myricetin and quercetin anticancer activity, Cancer Res. 66 (8) (2006) 4410-4418.

[70] G. Ozkan, S. Kamiloglu, T. Ozdal, D. Boyacioglu, E. Capanoglu, Potential use of turkish medicinal plants in the treatment of various diseases, Molecules 21 (2016) 257, doi:http://dx.doi.org/10.3390/molecules21030257.

[71] A.Y. Chen, Y.C. Chen, A review of the dietary flavonoid, kaempferol on human health and cancer chemoprevention, Food Chem. 138 (2013) 2099-2107.

[72] Y. Ting, Y. Chiou, M.H. Pan, C.T. Ho, Q. Huang, In vitro and in vivo anti-cancer activity of tangeretin against colorectal cancer was enhanced by emulsionbased delivery system, J. Funct. Foods 15 (2015) 264-273.

[73] M.H. Farzaei, R. Bahramsoltani, R. Rahimi, Phytochemicals as adjunctive with conventional anticancer therapies, Curr. Pharm. Des. 22 (2016) 1-18.

[74] R.O. Hynes, Integrins: versatility, modulation, and signaling in cell adhesion, Cell 69 (1992) 11-25.

[75] R. Haubner, W.A. Weber, A.J. Beer, E. Vabuliene, D. Reim, M. Sarbia, K.F. Becker M. Goebel, R. Hein, H.J. Wester, H. Kessler, M. Schwaiger, Noninvasive visualization of the activated alphavbeta 3 integrin in cancer patients by positron emission tomography and $\left[{ }^{18} \mathrm{~F}\right]$ Galacto-RGD, PLoS Med. 2 (2005) e70.

[76] M.R. Cominetti, C.H. Terruggi, O.H. Ramos, J.W. Fox, A. Mariano-Oliveira, M.S. De Freitas, C.C. Figueiredo, V. Morandi, H.S. Selistre-de-Araujo, Alternagin-C a disintegrinlike protein, induces vascular endothelial cell growth factor (VEGF) expression and endothelial cell proliferation in vitro, J. Biol. Chem. 279 (2004) 18247-18255.

[77] N. Nasr Bouzaiene, S. Kilani Jaziri, H. Kovacic, L. Chekir-Ghedira, K. Ghedira, J Luis, The effects of caffeic coumaric and ferulic acids on proliferation, superoxide production, adhesion and migration of human tumor cells in vitro, Eur. J. Pharmacol. 5 (2015) 99-105.

[78] Y.M. Tsai, C.J. Yang, Y.L. Hsu, L.Y. Wu, Y.C. Tsai, J.Y. Hung, C.T. Lien, M.S. Huang, P. L. Kuo, Glabridin inhibits migration, invasion, and angiogenesis of human nonsmall cell lung cancer A549 cells by inhibiting the FAK/rho signaling pathway, Integr. Cancer Ther. 10 (4) (2010) 341-349.

[79] J. Dai, P.G. Van Wie, L.Y. Fai, D. Kima, L. Wang, P. Poyil, J. Luo, Z. Zhang Downregulation of NEDD9 by apigenin suppresses migration invasion, and metastasis of colorectal cancer cells, Toxicol. Appl. Pharmacol. 311 (2016) 106112. 